\title{
Anchoring and adjustment effects on audit judgments: experimental evidence from Switzerland
}

\author{
Philipp Henrizi, Dario Himmelsbach and Stefan Hunziker \\ Lucerne University of Applied Sciences and Arts, Lucerne, Switzerland
}

\begin{abstract}
Purpose - The purpose of this study is to illustrate the potentially detrimental effects on audit decisionmaking of certain judgmental heuristics, which can lead to systematic judgmental biases. This paper provides background on the heuristics and biases approaches to decision-making to increase auditors' awareness of the anchoring and adjustment effects affecting audit judgments adversely.

Design/methodology/approach - This study reports the results of an experimental research design analyzing the audit judgment of 85 auditors in Switzerland.

Findings - Based on the results of the experiment, the results indicate evidence on the existence of the anchoring and adjustment heuristic in Swiss audit judgments. The authors could identify an influence of the audit company size, the auditors' experience and the auditors' knowledge about behaviorism and anchor heuristic with regard to the anchoring and adjustment effect on audit judgment.

Research limitations/implications - The experimental tasks were relatively simple abstractions from the more complex analytical review situations faced by practicing auditors. Due to the small sample size, the authors cannot ensure representativeness of the results.

Practical implications - Professional judgment is a skill that auditor acquires overtime, combined with experience and knowledge, that allows him to achieve reasonable judgments, being independent of other opinions and free from material biases in a given circumstance. Our results show that auditors who are aware of biases and heuristics are less prone to judgment biases.

Originality/value - This paper is the first to analyze the impact of auditors' explicit experience and knowledge about behaviorism and anchor heuristic on the anchoring and adjustment effect on audit judgment. Through a stronger awareness of cognitive biases, a professional skepticism can be enhanced.
\end{abstract}

Keywords Audit judgment, Heuristics and biases, Professional skepticism, Decision-making

Paper type Research paper

\section{Introduction}

Behaviorism is nowadays a pervasive topic in many disciplines of science and practice. During the last few decades, scientists and practitioners have been applying behavioral models to fields such as economics, medicine, psychology, sociology and politics. Research designs and methodologies from numerous studies in these fields were adapted to other fields of research such as audit, raising also the topic of behavioral audit. In the 1970s, US scientists of psychology such as Nobel laureate Tversky and Kahneman assessed the behavior of people and set up heuristically models that have dominated the judgment and decisionmaking literature ever since. They argued that humans make use of cognitive heuristics, which reduce the complexity of making probabilistic judgments (Tversky and Kahneman, 1974). Based on these models, several studies investigated on behavioral impacts on audit judgments, which helped to improve decision-making in auditing (e.g. Asthon, 1984; Bedard and Wright, 1994; Briggs and Wild, 1985; Butler, 1986; Joyce and Biddle, 1981; Kinney and Uecker, 1982; Kowalczyk and Wolfe, 1998; Prawitt, 1998; Presutti, 1995; Shanteau, 1989). Recent studies with regard to heuristics and biases in audit judgments (e.g. Bhattacharjee et al., 2012; Cheng, 2011; Lambert and Peytcheva, 2020; Pike et al., 2013) have demonstrated an impact on an individual's ability to exercise high-quality professional judgment. Thus, initial expectations influence auditors' application and performance of certain audit practices, like analytical audit procedures. Furthermore, interpersonal effects, such as can occur in the 
interaction between auditors and their clients, may affect the reliability of information. Therefore, a personality-based interpersonal influence can be an apparently irrelevant source characteristic that may inappropriately influence the auditors' assessment of source competence. These issues are important because auditors' accurate assessment of source reliability and interpretation of the outcome of audit procedures are critical to the effectiveness of the overall audit. It is thus important for auditors to understand behavioral aspects of audit in order to make appropriate judgments.

Professional skepticism is an essential component of every audit and the foundation for detecting fraud and maintaining an independent attitude resisting cognitive heuristics and biases (Farag and Elias, 2016). While the concept of professional skepticism has been part of auditing standards for decades (e.g. IAASB, 2012; IFAC, 2012; PCAOB, 2008), there is increasing recognition of both the importance of professional skepticism and deficiencies in the application of professional skepticism (e.g. Harding and Trotman, 2017; Hurtt, 2010; Quadackers et al., 2014; Westermann et al., 2016). Both researchers (e.g. Hurtt et al., 2013; Nelson, 2009) and regulators (e.g. IFAC and PCAOB) have emphasized the importance of exercising professional skepticism when conducting an audit. An auditor with a high degree of professional skepticism is more likely to make skeptical judgments that may, in turn, generate observable skeptical actions/outcomes that manifest as a conservative approach to the audit (Nelson, 2009). However, professional skepticism remains difficult to define and measure. Various sources have defined professional skepticism as an attitude that includes a questioning mind and a critical assessment of evidence (AICPA, 2007), the ability to detect fraud (Choo and Tan, 2000), the opposite of trust (Shaub, 1996), a conservatism bias in audit judgment (McMillan and White, 1993), the equivalent of independence (Kadous, 2000) and presumptive doubt (Nelson, 2009). Research has indicated several possible factors influencing auditors' skepticism: individual auditor characteristics, evidential characteristics, client characteristics or external environmental characteristics may affect the ability of an auditor to recognize situations where additional work or investigation is required (for a detailed listing of possible influential factors, see Hurtt et al., 2013). In particular, the influence of training of skeptical judgments and critical thinking as well as experience or expertise in auditing was noted (e.g. Bucaro, 2019; Gao and Zhang, 2019; Knechel et al., 2010; Olsen and Gold, 2018; Peecher et al., 2007; Wedemeyer, 2010). In summary, although academic research has begun to address professional skepticism, it remains a topic where there are many more questions than answers. Only a few notable studies on anchoring and adjustment effects on audit judgments have been published ever since, investigating the interplay of several factors to shed light on the complexity of skeptical auditor behavior.

Accordingly, the main purpose of this study is to illustrate the potentially detrimental effects on audit decision-making of certain judgmental heuristics, which can lead to systematic judgmental biases. The aim of this study is to increase auditors' awareness of some of the subtle biases that can adversely affect audit decision-making, and - hopefully - to improve their abilities to avoid such biases and maintain an attitude of professional skepticism in audit judgments. The current study adds to the existing literature in several ways. First, to the best of our knowledge, this is the first study analyzing the impact of auditors' explicit experience and knowledge about behaviorism and anchor heuristic on the anchoring and adjustment effect on audit judgment. Through a stronger awareness of cognitive biases, a professional skepticism can be enhanced. Second, this analysis extends prior research by distinguishing between Big Four and non-Big Four auditors. Larger audit firms (i.e. Big Four) have a reputation of providing higher-quality audit services than smaller firms (i.e. non-Big Four) (e.g. Chen and Wang, 2018). Therefore, Big Four firms likely have more of an incentive, relatively to smaller audit firms, to ensure that adequate levels of professional skepticism are maintained in order to promote higher audit quality (e.g. Cohen et al., 2017; Eshleman and Guo, 2014; Teoh and Wong, 1993). Big Four firms establish various 
training and control mechanisms to maintain consistency in audit quality (Bedard et al., 2008; Dowling and Leech, 2014; Jenkins et al., 2008) and usually develop more effective in-house standardized audit procedures and review systems (Blokdijk et al., 2006; Choi et al., 2010). Analyzing the impact of knowledge about bias and heuristic and the effect of higher standardized audit procedures on audit judgment addresses the request by Hurtt et al. (2013) for further research on how professional skepticism can be enhanced. In addition, these two issues are also useful for auditing educators, showing that both knowledge about behaviorism and anchor heuristic and higher standardized audit procedures might lead to less biased audit judgment. Thirdly, this is the first paper to analyze the anchoring and adjustment effects on audit judgments in Europe, which contribute to reducing the lack of knowledge and awareness on this issue in Europe. In particular, the audit market in Switzerland is very much dominated by SMEs, where often only a limited audit is carried out. In the context of these audits, the audit opinion relies to a greater extent on analytical audit procedures. Against this background, an investigation of the adverse effects of cognitive heuristics on Swiss auditors seems to be very relevant.

The remainder of the paper is organized as follows. The next section provides some theoretical background and a literature review on the bias of anchoring effects in a financial audit. The third section addresses the research methodology, including the presentation of the hypotheses and the approach to data collection. The fourth section presents the empirical results, while the final section provides a discussion of the results and draws conclusions.

\section{Background and literature review}

\subsection{Heuristics and biases}

Simon (1957) described heuristics as limited rationality due to cognitive limitations. Simon argued that heuristics are simplified models of the complex world that enable people to make decisions more efficiently. Tversky and Kahneman (1974) see heuristics as "mental shortcuts," which allow people to form judgments with incomplete information. Therefore, heuristics are not only restricted to laymen, but experts (e.g. partners in audit firms) are also prone to biases. Nevertheless, the authors mention that heuristics are quite useful but sometimes lead to systematic errors. Gilovich and Griffin (2013) define biases as deviations from rational thinking. These deviations (i.e. biases) are underlying assumptions for a model or rules, and the authors point out that most of the observed biases violate basic laws of statistics and probability. As a result, people may draw an irrational or false conclusion from their model (i.e. heuristic). Returning to the example of the distance estimation, the bias here would be, among many others, the omission of the visibility condition in the model. To sum up, decisions are often based on beliefs about an outcome of uncertain events.

Kahneman and Tversky (1973) define three heuristics which occur when predicting values and assessing probabilities (representativeness, availability and anchoring and adjustment).

As the anchoring and adjustment heuristic is subject to this study, the underlying theory is discussed in more detail. This heuristic is often used when people are given an anchor (i.e. initial value, starting point) and need to make estimates. Whether that happens consciously or not, people tend to adjust their estimate from the anchor until they have reached an acceptable level. It does not matter whether the anchor is random or a result of previous calculation, the adjustments from those anchors are often insufficient since these estimates are all biased toward the anchor (Slovic and Lichtenstein, 1971). Following Wilson et al. (1996), the anchoring and adjustment process is illustrated in Figure 1 and described as follows:

Figure 1.

The anchoring and adjustment process following Wilson et al. (1996) 
The anchoring and adjustment process starts with a subject considering an anchor as a possible answer to derive from. Thereby, anchors could be expectations, information from the past or information provided by others (e.g. supervisors, experts). According to Wilson et al. (1996), however, anchors do not necessarily have to be linked to the estimate. They argue that even arbitrary information can be taken as an anchor when better information is absent.

Once an anchor has been considered as a plausible answer, the subject begins to consult its memory and gathers information about the feature of the target (Wilson et al., 1996). Chapman and Johnson (1999) state that this confirmatory search is a critical point in the whole anchoring and adjustment process as subjects tend to focus more on reasons of similarity between anchor and target than on reasons of difference. Asking subjects about the count of doctors in their neighborhood with a provided anchor of 3,000, people rather retrieve information and reasons from memory on why this number is consistent with the target. As a result, subjects already influence their estimate by way of retrieving information (Wilson et al., 1996).

The third step of the anchoring and adjustment process is about the integration of the target in the decision-making process. At this point, subjects integrate their target value from the previous step into consideration and compare it to the anchor. Now subjects start to adjust away from the anchor until having reached sufficient adjustment in order to answer the questions (Wilson et al., 1996). However, many studies conclude that these adjustments are often said to be insufficient (see, e.g. Ashton, 1984; Epley and Gilovich, 2006; Tversky and Kahneman, 1974).

One might argue that from an economic point of view, these heuristics might be seen as effective. However, all heuristics bear systematic errors and may lead to wrong conclusions. A better understanding of these heuristics may thus improve judgments and decisions when dealing with uncertainty (Tversky and Kahneman, 1974).

\subsection{Judgment and decision-making in analytical audit procedures}

As auditing is the research field of this study, it is important to discuss this environment with regards to behaviorism. The audit procedures, which are most affected by behavioral aspects like the anchoring and adjustment heuristic, are analytical procedures (Kinney and Uecker, 1982; Biggs and Wild, 1985; see also Mactavish et al., 2018 for an overview). According to the International Auditing and Assurance Standards Board (IAASB), the analytical audit procedures are defined as "evaluations of financial information through analysis of plausible relationships among both financial and non-financial data” (ISA 520, Para. 4). Hence, analytical audit procedures involve a comparison of the amounts recorded to auditors' expectations. Therefore, it is required that a single financial position or the relations between two and more positions are predictable (Arens et al., 2012; SAS 520, Para. A15).

According to the Swiss Audit Standards (SASs), analytical audit procedures can be deployed for the planning, execution and closing in audit (SAS 520, Para. A8, A10 and A13). Whereas analytical audit procedures for the execution of the statutory audit are facultative, they must be deployed for the audit planning and completion phase. However, auditors are also encouraged to make use of analytical audit procedures during the testing phase. Especially for limited statutory examinations and reviews, auditors often make use of analytical procedures during the execution phase (Kartscher et al., 2013). A detailed overview of the timing and purposes of analytical procedures is provided by Table 1.

Since evidence from analytical audit procedures is often easier to obtain than test of details, they are also extensively used during the testing phase in practice (Arens et al., 2012). The main purposes of analytical audit procedures are the following: 
(1) To assess the ability of an entity to continue as a going concern

(2) To detect material misstatements in the financial statements

(3) To reduce test of details

The usual process of analytical audit procedures according to SAS 520 can be illustrated as exhibited in Figure 2.

An auditor has to first evaluate the reliability of the data and form an expectation. Auditors acquire information from different sources that are relevant to a certain audit field. Such sources might be past audited figures, economic indicators, industry benchmarks and so forth. Biggs and Wild (1985) exempt unaudited figures as an appropriate source since theory would violate the rule that auditors make independent evaluations. Unaudited book values are regarded as so-called "management assertions" and thus require professional skepticism of the auditors involved. However, neither IAASB nor the Swiss Fiduciary Chamber explicitly exempts unaudited figures from the list of sources where auditors derive their expectations from (e.g. Biggs and Wild, 1985; Treuhand-Kammer, 2013). It is the task of the auditor to assess the validity, relevance and comparability of the outcome of such audit procedures (SAS 520, Para. A4 and A5). Once the auditor has gathered sufficient information about the audit field, he or she starts to develop an expectation. The expectation must be independent, which means that the auditor may not solely rely on the client's data and maintain an attitude of professional skepticism (Rodgers et al., 2017). Whereas an independent expectation of depreciation on non-current assets is rather easy to form, it may be difficult to do so for a new product launch. As an independent expectation requires a sound knowledge of the client and industry, it is sometimes impossible to obtain sufficient evidence from analytical audit procedures (Kartscher et al., 2013). The expectation can be based either on statistical inference and/or on their professional judgment.

The second step is the definition of acceptable deviations of the expected figure(s). The acceptable deviations need to be based on materiality and the risk of the respective audit field. In a third step, the auditor compares the unaudited figure(s) with the expected value and checks whether the deviation lies within the set non-investigation region or not. As long as the computed deviation lies within the acceptable range, the auditor may complete the analytical procedure. Otherwise, it is necessary to obtain further evidence in order to explain the correctness and accuracy of the deviation in a fourth step (SAS 520, Para. A16). For deviations within the non-investigation region, the auditor may reduce the degree of test of details. Otherwise, auditors have to conduct further investigation to explain the difference. The extent of further investigation is left to the auditor and in dependence upon professional judgment (SAS 520, Para. A8 and A9).

\begin{tabular}{llll}
\hline Purpose & Planning phase & $\begin{array}{c}\text { Purpose during phase } \\
\text { Testing phase }\end{array}$ & Completion phase \\
\hline Assess premise of going concern & Secondary & & Secondary \\
Detect material misstatements & Primary & Secondary & Primary \\
Reduce test of details & Secondary & Primary &
\end{tabular}

Note(s): This table exhibits the purposes of analytical audit procedures for each phase of the audit

Table 1.

Timing and purposes of analytical procedures

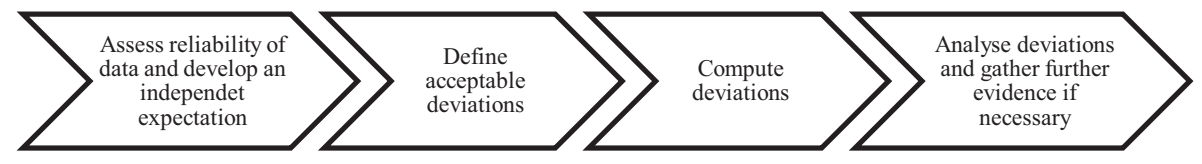


According to Kartscher et al. (2013), auditors often spend the most time on step four instead on the first step, which is, however, the most important and most complex one. In step one, auditors are also deemed to be most prone to cognitive pitfalls such as neglecting statistical rules and anchoring effects produced by unaudited data. It is thus important that auditors are familiar with behavioral aspects of auditing.

Since time and cost constraints usually arise in audit, many auditors refrain from running statistical extrapolations (see Biggs and Wild, 1985; Kinney and Uecker, 1982). Therefore, professional judgment and professional skepticism are crucial for developing "good" expectations. Hence, an auditor must plan and carry out the audit in the knowledge that the financial statements may contain material misstatements. Thereby, an auditor must scrutinize the client's information and documents for reliability. Furthermore, professional skepticism is insofar important as it prevents auditors from overlooking unusual circumstances and drawing generalized conclusions (SAS 200, Para. A18). Professional judgment is deemed important throughout the planning and performance of the audit since appropriate conclusions can only be drawn if having sound knowledge and experience in auditing (SAS 200, Para. A23). However, the assessment of circumstances shall not solely rely on own expectations and experience of the auditor, as these factors do not constitute appropriate measures (Framework of Assurance Engagements, Article 36).

\subsection{Prior research}

Even though many studies confirm the existence of anchoring effects in financial audit, they often reveal mixed results regarding the magnitude of such effects (e.g. Biggs and Wild, 1985; Butler, 1986; Joyce and Biddle, 1981; Kinney and Uecker, 1982; Kowalczyk and Wolfe, 1998).

Joyce and Biddle (1981) investigate the effects of anchoring and adjustment on probabilistic inferences in auditing judgment. They conducted six experiments to determine the extent of effects on practicing auditors' judgments. The authors conclude that auditors sometimes violate normative principles of decision-making, but such violation cannot always be directly linked to anchoring effects, which indicates that unknown heuristics might be latent. An extension of this research by Wright and Anderson (1989) indicate anchoring effects as robust. Also, Kinney and Uecker (1982) reveal that the anchoring and adjustment heuristic is present in analytical reviews. However, they also observe that the anchoring effect does not always occur (i.e. insignificant results), and the magnitude of the anchoring effect is also influenced by other factors. These studies typify the somewhat confusing state of affairs about the role of heuristics and biases in auditing judgment.

Adapting the experimental case of Kinney and Uecker (1982), where participants received two years of audited figures and biased unaudited figures, Biggs and Wild (1985) demonstrate the anchoring effect among auditors in the performance of preliminary analytical review procedures. Both of these studies show that unaudited values, which should be ignored in independent evaluations, influence the investigative boundary values selected by auditors. These results suggest that the auditors are apparently unable or unwilling to ignore the anchoring information in their judgments. Even though the analysis of both studies yields significant results, Kinney and Uecker (1982) state a higher level of significance. However, both studies provide some evidence, that the anchoring and adjustment heuristic pervades a variety of judgments and is merely applied to probabilistic inference.

Further, Butler (1986) detects existence of anchoring effects in auditing as well; he scrutinized previous results with high significance levels (see Joyce and Biddle, 1981; Kinney and Uecker, 1982). Possible reasons for Butler's (1986) different results might derive from the different statistical model applied ( $t$-test instead of chi-square test) and that all his 
participants have at least two years of experience in auditing, whereas the samples of the previous studies also include auditors with less experience including assistants. This finding is insofar interesting as this fact indicates that more experienced auditors are less prone to biases.

Kowalczyk and Wolfe (1998) set out to examine in a going concern context whether a recommendation from a decision aid serves as an anchor from which auditors insufficiently adjust when confronted with additional information not accounted for by the aid. The results provide evidence that anchoring effects can occur with the provision of recommendations from the expert decision aid. An important implication of these results is that anchoring on the advice of an expert decision aid can result in improper attention given to audit evidence, which is inconsistent with the recommendation.

Moreover, Ashton (1984) infers that the use of heuristic may be beneficial as it helps to simplify the decision-making process and saves, therefore, time and cognitive effort. It is also possible that the use of heuristics may yield on acceptable judgment. However, even though heuristics can be efficient in decision-making, the use of heuristics in auditing can lead to systematic errors and inconsistencies (Ashton, 1984; Libby, 1981; Tversky and Kahneman, 1974). Nevertheless, the cost of the alternative assessment that eliminates the bias may outweigh the gained benefit (Joyce and Biddle, 1981; Thorngate, 1980). This might be a reason why heuristic procedures are still employed in audit judgments. Especially because heuristics are continuously applied in practice, a better understanding of heuristics would improve decision-making under uncertainty (Ashton, 1984; Epley and Gilovich, 2001; Tversky and Kahneman, 1974).

The danger of relying on heuristics is also that the harmful effects of using heuristics often remain unrecognized. The reliance on heuristics is not restricted to laymen; also experienced people are prone to heuristics when thinking intuitively (Tversky and Kahneman, 1974). Ashton (1984) concludes that also auditors were not even aware of employing heuristics in their decision-making process (see also Kennedy, 1995; Smith and Kida, 1991).

Behavioral researchers have been concerned about the effect of heuristics on decisionmaking, especially in highly technical fields such as auditing, and have put effort into investigating significant factors influencing auditor judgment. Abdolmohammadi and Wright (1987) provide evidence that experience has a significant effect when task complexity is explicitly considered. Bonner (1999) differentiates the experience effect, specifically the role of task-specific knowledge, in the cue selection and cue weighting of components of analytical risk assessment and control risk assessment. The results show that task-specific experience aids the performance of auditors. Moreover, auditors with specialized industry knowledge have a higher skeptical judgment when working within their industry specialization, which results in less biased audit decisions (Low, 2004; Owhoso et al., 2002; Solomon et al., 1999).

Furthermore, Hackenbrack (1992) reveals an influence of nondiagnostic (i.e. irrelevant) and diagnostic (i.e. relevant) information on auditor judgment. Auditors given a mix of relevant and irrelevant evidence make fraud-risk assessments that are less extreme (more regressive) than those based on relevant evidence only. This behavior is consistent with the nonnormative judgment tendency known as the dilution effect (see Nisbett et al., 1981). Using a different task and context than Hackenbrack, Glover (1997) extends this study in examining the influence of nondiagnostic information on auditor judgment and analyzing whether auditors exhibit the dilution effect when faced with time pressure and accountability. The imposition of time pressure significantly reduces, but does not eliminate, the dilution effect. That time pressure influences auditor judgment is consistent with previous audit research, demonstrating that contextual variables influence judgment (e.g. Ashton, 1990; McDaniel, 1990). Contrary to findings in psychology, accountability had no significant influence on the dilution exhibited by auditors. Hoffman and Patton (1997) also find that accountability did not exacerbate the dilution effect in another area of auditor judgment. Shelton (1999) finds 
that experience reduces the influence of irrelevant information on auditor judgment. More experienced auditors are not influenced by the presence of irrelevant information in making a going concern judgment. However, consistent with prior research (Hackenbrack, 1992; Hoffman and Patton, 1997; Glover, 1997), less-experienced auditors are influenced by the presence of irrelevant information.

More recent studies like Amir et al. (2014), Gul et al. (2013), He et al. (2018) and He et al. (2017) have shown that the characteristics of an auditor influence professional skepticism and quality of the audit being undertaken. The individual auditor effects on audit quality can be partially explained by auditor characteristics, such as attitude toward risk, educational background, experience, rank in the audit firm and political affiliation (Amir et al., 2014; Gul et al., 2013). Further, the economic conditions at the time an auditor enters the labor market have a long-term impact on his or her judgment and decision-making. Specifically, engagement partners who started their career during economic downturns issue audit adjustments more frequently (He et al., 2018). Besides, social ties between engagement auditors and audit committee members shape audit outcomes Although these social ties can facilitate information transfer and help auditors mitigate management pressure to waive correction of detected misstatements, cozy interpersonal relations can undermine auditors' monitoring of the financial reporting process (He et al., 2017).

There have been several studies on how to avoid contaminated judgment from a behavioral point of view. A study by Wilson et al. (1996), for instance, outlines possible conditions that must be met preventing people from biased decision-making. First, people must be aware of the existence of the bias. Furthermore, they must also be willing to correct the bias, having knowledge about the magnitude of the bias and having a certain level of self-control over their answers. Even if people are aware of the persistence of the biases and have sufficient motivation to prevent them, it may be difficult to evaluate the magnitude of the bias and thus to tell by how much their answers have been affected. As a result, it is difficult avoiding anchoring effects even if people know they may occur (Wilson et al., 1996). In addition, Wilson et al. (1996) also find evidence for anchoring effects even though the participants were told not to use the provided anchors when answering the questions. Interestingly, also people's motivation and physical condition have an effect on judgments. Auditors' intrinsic motivation for their work provides unique value for improving professional skepticism and judgment quality (Kadous and Zhou, 2019). Also, according to Epley and Gilovich (2006), people tend to adjust more accurately for their answers when being motivated and mentally fit (i.e. no stress or signs of tiredness). Unfortunately, further conclusive results have not emerged over the 40 years of research on the anchoring and adjustment heuristic - the reason why adjustments tend to be insufficient remains unclear (Epley and Gilovich, 2006).

\section{Methodology and research design}

In order to examine the existence of anchoring and adjustment heuristic and to assess the extent of biased audit judgments in Switzerland, we designed an experiment, which we conducted with auditors of ten different Swiss audit companies, ranging from local to multinational audit firms. Based on the presented empirical results of previous studies regarding the anchoring effects in financial audit, we hypothesize:

H1. There are differences in Swiss audit judgment with regard to the bias deriving from the anchoring and adjustment heuristic.

We build on the extant literature on audit quality and assume that Big Four accounting firms perform higher-quality audits than non-Big Four auditors in both public (e.g. DeFond et al., 2016) and private markets (e.g. Che et al., 2017). A substantial body of empirical literature 
suggest that Big Four firms, which potentially have more to lose from a loss of reputation, plus a higher level of expected audit quality, are more likely to demonstrate high levels of professional skepticism (e.g. Cohen et al., 2017; Eshleman and Guo, 2014; Teoh and Wong, 1993). Thus, large audit firms tend to place more emphasis on staff training and/or peer review within the firm, and are more likely to use standardized audit procedures and techniques (e.g. computerized audit procedures), compared with small audit firms (e.g. Bedard et al., 2008; Dowling and Leech, 2014; Jenkins et al., 2008; Knechel et al., 2018). In addition, Big Four firms generally have more resources (Johnson et al., 2002) and a greater access to the support of a large international network (Lenz and James, 2007), which can offset idiosyncratic auditor differences in the audit process. Therefore, we suggest that Big Four firms' pervasive monitoring processes, compared to that of non-Big Four firms, are likely to dampen the effect of anchoring and adjustment heuristic on auditor decisions. Thus, we are testing the following hypothesis:

H2. There are differences in Swiss audit judgments with regard to the anchoring and adjustment heuristic between Big Four and non-Big Four auditors.

Several researchers have observed that professional skepticism enhances audit quality. For instance, findings show that auditors with a high level of professional skepticism identify more contradictions in client explanations (Hurtt et al., 2013), rely less on clients' explanations (Quadackers et al., 2014), are better able to recognize unethical behavior (Rose, 2007) and are more successful in spotting fraud-related cues (Hayes, 2016; Popova, 2013). Further studies reveal that auditors with more experience in conducting financial audits show more professional skepticism, presumably because of the greater audit understanding and the ability to make more skeptical judgments gained through experience (e.g. Hurtt et al., 2013; Knechel et al., 2010; Nugraha and Suryandari, 2018; Peecher et al., 2007; see also Mala and Chand, 2015 for an overview). Experience is meant here in terms of general audit experience (i.e. both the length of time and the number of audits that have been done). We then expect that auditors with more years of experience might tend to be less prone to biases deriving from the anchoring and adjustment heuristic, leading to our next hypothesis:

H3. There are differences in Swiss audit judgments with regard to the anchoring and adjustment heuristic with respect to the auditors' experience.

Tversky and Kahneman (1974) describe the availability heuristic, which indicates that people assess the probability of an event occurring based on the ease with which examples of that event can be brought to mind. Consequently, knowledge about or familiarity with behaviorism makes the awareness against cognitive biases event more available. Based on Tversky and Kahneman's findings, the likelihood or probability assessed by an individual that during a certain audit judgment a risk of an anchoring and adjustment heuristic may exist should be directly related to whether the individual can easily recall cognitive biases. As mentioned before, Wilson et al. (1996) emphasize people being aware of the existence of behaviorism and cognitive biases are better equipped to resist the anchoring heuristic. Thus, our last hypothesis reads as follows:

H4. There are differences in Swiss audit judgments with regard to anchoring and adjustment heuristic in respect of the auditors' knowledge of behavioral audit.

\subsection{Experimental design}

For the purpose of testing these hypotheses, we developed an online survey containing five experimental cases and a post-experimental questionnaire regarding the participants' experience of being influenced by data or clients and knowledge of behaviorism, which is 
relevant to assess the importance of increasing the awareness of cognitive pitfalls in audit judgments. A link to that online website was sent via email to randomly selected external auditors with the request to participate in our study. The participants were randomly assigned either to the control or experimental group. Thereby, the experimental group received the same information as the control group, except for the planned heuristics that we tested for. The survey was tested before it was sent out to the participants. During that pre-testing period, several students tested the survey and provided feedback that led to a few minor but valuable adjustments to the final survey.

Once the participants accessed the website, they were provided with a brief explanation of the nature of the task before the five cases were presented. Four out of these five experimental cases have been adapted from former studies in behavioral audit and one was created by the authors themselves. The five cases comprise different characterizations of anchors, which are shown in Table 2.

For more details, see the five experimental cases presented in the Appendix. Table 3 provides an overview of all dependent variables used in this study including a brief definition.

After the case exercises, all participants were asked the same post-experimental questions. Those questions dealt with topics such as perception of influence, working under time and budget constraints, knowledge about behaviorism and personal data such as sex, age, employer, working position and years of experience in auditing. The participants were not able to get back to the experimental task when they were working on the postexperimental questionnaire.

Table 2. Anchor 3 characterization of the 4 experimental cases

\begin{tabular}{llll}
\hline No. Case & Type of anchor & Bias & Original source \\
\hline 1 & Internal anchor & Mean-reverting level & Kinney and Uecker (1982) \\
2 & External anchor & Arbitrary information & Own creation \\
3 & External anchor & Arbitrary number & Joyce and Biddle (1981) \\
4 & Internal anchor & Formulation of probability estimate & Joyce and Biddle (1981) \\
5 & Internal anchor & Insufficient adjustment from own anchor & Joyce and Biddle (1981) \\
\hline
\end{tabular}

\begin{tabular}{|c|c|c|}
\hline $\begin{array}{l}\text { No. } \\
\text { case }\end{array}$ & Variable & Definition \\
\hline \multirow[t]{2}{*}{1} & LB & $\begin{array}{l}\text { Lower bound of indicated range of possible values of gross profit percentage the } \\
\text { participants feel that an investigation should be conducted to "explain" the apparent } \\
\text { change in gross profit percentage for unaudited } 2016 \text { figures (in \%) }\end{array}$ \\
\hline & UB & $\begin{array}{l}\text { Upper bound of indicated range of possible values of gross profit percentage the } \\
\text { participants feel that an investigation should be conducted to "explain" the apparent } \\
\text { change in gross profit percentage for unaudited } 2016 \text { figures (in \%) }\end{array}$ \\
\hline 2 & $\mathrm{FV}$ & Participant's estimate of the fair value of the building (in CHF) \\
\hline 3 & $\begin{array}{l}\text { MGTF } \\
\text { EST }\end{array}$ & $\begin{array}{l}\text { Participants best estimate of Big Four clients per X that have significant management } \\
\text { fraud (in CHF) } \\
\text { While X being } 100 \text { for the experimental and 1,000 for the control condition }\end{array}$ \\
\hline 4 & $\mathrm{GC}$ & $\begin{array}{l}\text { Participant's estimate on the probability of success of a company's proposed new } \\
\text { product line, which is deemed necessary for the client to remain a going concern (in \%) }\end{array}$ \\
\hline 5 & PI & $\begin{array}{l}\text { Participants were provided with eight statements about internal controls on which } \\
\text { they had to indicate the extensiveness of the substantive tests they would perform in } \\
\text { that engagement using a 10-point scale anchored on } 1=\text { minimum extensiveness to } \\
10=\text { maximum of substantive testing procedure }\end{array}$ \\
\hline
\end{tabular}

Table 3.

Variable definition

\section{$10=$ maximum of substantive testing procedure}




\subsection{Participants}

A total of 103 external auditors participated and were randomly assigned to the control or experimental condition. Non-respondents might have different opinions; therefore, we compared the answers of the early and the late respondents. The comparison did not reveal essential differences between the two groups, which does not indicate a non-response bias. However, 18 responses had to be eliminated due to non-completion of the survey. These records were deemed unusable as they did not contain crucial information such as the participant's age, sex, years of experience and the audit firm working for. The reported results are based on the responses from the remaining 85 participants from more than ten different Swiss audit companies. Thereof, $19 \%$ were female and $81 \%$ male representing all linguistic regions from Switzerland. Furthermore, the participants' age ranged from 23 to 57, with corresponding years of experience of one to a maximum of 23 , respectively. In all, $52.9 \%$ of the participants were manager/partner being licensed certified public accountants. Table 4 summarizes the demographic statistics of the participants of the experiment.

\section{Results}

\subsection{Analytical statistics}

In order to demonstrate the anchoring and adjustment effects between the control and experimental group, we ran a Mann-Whitney $U$ test [1] over all variables of the five experimental cases, because the collected data are not normally distributed. The results of the analytical statistics provided in Table 5 indicate the existence of biased audit judgments.

As demonstrated in Table 5, all experiments have significant results with regard to the existence of anchoring and adjustments effects in Swiss audit judgments. The results of the analysis exhibit statistically highly significant anchoring effects on LB ( $U=532.500$, $z=3.331, p=0.001, r=0.361)$ and $\mathrm{UB}(U=463.000, z=3.922, p=0.000, r=0.425)$ of the first experimental case. Even though from a mathematical point of view both conditions should have come to the same conclusion, the medians in $\mathrm{LB}(C=15, E=16)$ and $\mathrm{UB}$ $(C=19.8, E=20)$ differ significantly with a medium effect size.

Also, in the second experimental case, estimating the fair value of a building employing the discounted cash flow model results in FV $(U=412.500, z=4.372, p=0.000)$ being highly significant. With $r=0.474$, FV reveals the strongest effect of all variables tested. The additional information provided to the experimental group, which should not influence the objective judgments of an auditor, provokes a change in median fair value estimates of $\mathrm{CHF}$ $15,000,000$ to CHF 11,145,000, which is $25.7 \%$ less.

\begin{tabular}{|c|c|c|c|c|c|c|}
\hline & & & & $N$ & $\%$ & \\
\hline $\begin{array}{l}\text { Category of the audit firm } \\
\text { Big Four } \\
\text { Non-Big Four }\end{array}$ & & & & $\begin{array}{l}64 \\
21\end{array}$ & $\begin{array}{l}75.3 \\
24.7\end{array}$ & \\
\hline $\begin{array}{l}\text { Position } \\
\text { Assistant } \\
\text { Manager/partner (CPA's) }\end{array}$ & & & & $\begin{array}{l}40 \\
45\end{array}$ & $\begin{array}{l}47.1 \\
52.9\end{array}$ & \\
\hline $\begin{array}{l}\text { Gender } \\
\text { Female } \\
\text { Male }\end{array}$ & & & & $\begin{array}{l}16 \\
69 \\
\end{array}$ & $\begin{array}{l}18.8 \\
81.2\end{array}$ & \\
\hline & $N$ & Mean & $\mathrm{SD}$ & Min & $\operatorname{Max}$ & \\
\hline $\begin{array}{l}\text { Age } \\
\text { Years of experience }\end{array}$ & $\begin{array}{l}85 \\
85\end{array}$ & $\begin{array}{r}34.19 \\
9.67\end{array}$ & $\begin{array}{l}9.65 \\
8.83\end{array}$ & $\begin{array}{r}23 \\
1\end{array}$ & $\begin{array}{l}57 \\
35\end{array}$ & $\begin{array}{r}\text { The participants' } \\
\text { demographic data }\end{array}$ \\
\hline
\end{tabular}




\begin{tabular}{|c|c|c|c|c|c|c|c|c|c|c|}
\hline & $\begin{array}{l}\text { No. } \\
\text { Case }\end{array}$ & Variable & Condition & $N$ & Median & $\begin{array}{l}\text { Mean } \\
\text { rank }\end{array}$ & $U$ & $z$ & $\begin{array}{l}p \text {-value (exact } \\
\text { sig. } 2 \text {-tailed) }\end{array}$ & $r$ \\
\hline & 1 & LB & $\begin{array}{l}\mathrm{C} \\
\mathrm{E}\end{array}$ & $\begin{array}{l}43 \\
42\end{array}$ & $\begin{array}{l}15 \\
16\end{array}$ & $\begin{array}{l}51.62 \\
34.18\end{array}$ & 532.500 & 3.331 & 0.001 & 0.361 \\
\hline & & UB & $\begin{array}{l}\mathrm{C} \\
\mathrm{E}\end{array}$ & $\begin{array}{l}43 \\
42\end{array}$ & $\begin{array}{l}19.8 \\
20\end{array}$ & $\begin{array}{l}53.23 \\
32.52\end{array}$ & 463.000 & 3.922 & 0.000 & 0.425 \\
\hline & 2 & $\mathrm{FV}$ & $\begin{array}{l}\mathrm{C} \\
\mathrm{E}\end{array}$ & $\begin{array}{l}43 \\
42\end{array}$ & $\begin{array}{l}15,000,000 \\
11,145,000\end{array}$ & $\begin{array}{l}54.41 \\
31.32\end{array}$ & 412.500 & 4.372 & 0.000 & 0.474 \\
\hline & 3 & MGTF_EST & $\begin{array}{l}\mathrm{C} \\
\mathrm{E}\end{array}$ & $\begin{array}{l}43 \\
42\end{array}$ & $\begin{array}{l}40 \\
90\end{array}$ & $\begin{array}{l}53.40 \\
32.36\end{array}$ & 456.000 & 3.967 & 0.000 & 0.430 \\
\hline & 4 & $\mathrm{GC}$ & $\begin{array}{l}\mathrm{C} \\
\mathrm{E}\end{array}$ & $\begin{array}{l}43 \\
42\end{array}$ & $\begin{array}{l}60 \\
60\end{array}$ & $\begin{array}{l}48.66 \\
3720\end{array}$ & 659.500 & 2.171 & 0.030 & 0.235 \\
\hline $\begin{array}{l}\text { Table } 5 \text {. } \\
\text { Test of hypothesis } 1 \\
\text { over all }\end{array}$ & 5 & PI & $\begin{array}{l}\mathrm{L} \\
\mathrm{C} \\
\mathrm{E}\end{array}$ & $\begin{array}{l}42 \\
42\end{array}$ & $\begin{array}{l}3 \\
2\end{array}$ & $\begin{array}{l}51.33 \\
34.48\end{array}$ & 545.000 & 3.238 & 0.001 & 0.351 \\
\hline
\end{tabular}
experimental cases

Note(s): This statistics provided in this table derive from the M-W test with a significant level of 0.05

In the third experimental case, this change of the anchor from 10 to 100 demonstrates the following statistics for MGTF_EST $(U=456.000, z=3.967, p=0.000, r=0.430)$, with median management fraud estimation score for the control condition (40, i.e. $4 \%$ ) and the experimental condition (90, i.e. $9 \%$ ) being more than double as in the control group. The number 10 or 100 is irrelevant for making an estimate. Therefore, the mean ratio should rather be the same in both groups.

The fourth experimental case exhibits equal medians for both conditions; however, the test in differences between them remains statistically significant. This is due to the rank sum of both conditions that differs enough to be statistically significant. Nevertheless, this has an impact on $\mathrm{GC}(U=659.000, z=2.171, p=0.030, r=0.235)$, it being the only variable that does not demonstrate highly significant test results.

Moreover, Table 5 also verifies significant results for the fifth experimental case and the variable $\mathrm{PI}(U=545.000, z=3.238, p=0.001, r=0.351)$ providing evidence that declaring two internal controls as unsatisfactory in the hindsight is believed to have a greater misstatement risk impact on the financial statement, since the median of extent of the substantive test varies significantly from 3 for the control group to 2 for the experimental group with a medium effect size.

Overall, these statistical analyses provide sufficient evidence that anchoring and adjustment heuristics are employed in Swiss audit judgments. All variables in Table 5 exhibit a statistically high significance, except for GC with a corresponding $p=0.030$ that is still considered significant. Consistent with our expectations, auditors in Switzerland employ the anchoring and adjustment heuristics, and thus the Hypothesis 1 is maintained.

Table 6 demonstrates the statistical test of Hypothesis 2, if there are differences in Swiss audit judgments with regard to the anchoring and adjustment heuristic between Big Four and non-Big Four audit firms since bigger audit firms have more standardized audit procedures which might result in less biased audit decisions. Comparing the test statistics between the Big Four and the non-Big Four firm groups, the findings indicate that auditors of a Big Four firm are less prone for the anchoring and adjustment heuristic compared to non-Big Four auditors, since only three of five experimental cases reveal significant differences between the control and experimental groups. For the group of non-Big Four auditors, four out of five experimental cases are statistically significant, and the significant results have even a higher effect size. The variable FV, for example, has for the Big Four group a $p$-value of $p=0.047$ and an effect size of $r=0.435$, which is barely significant with a 


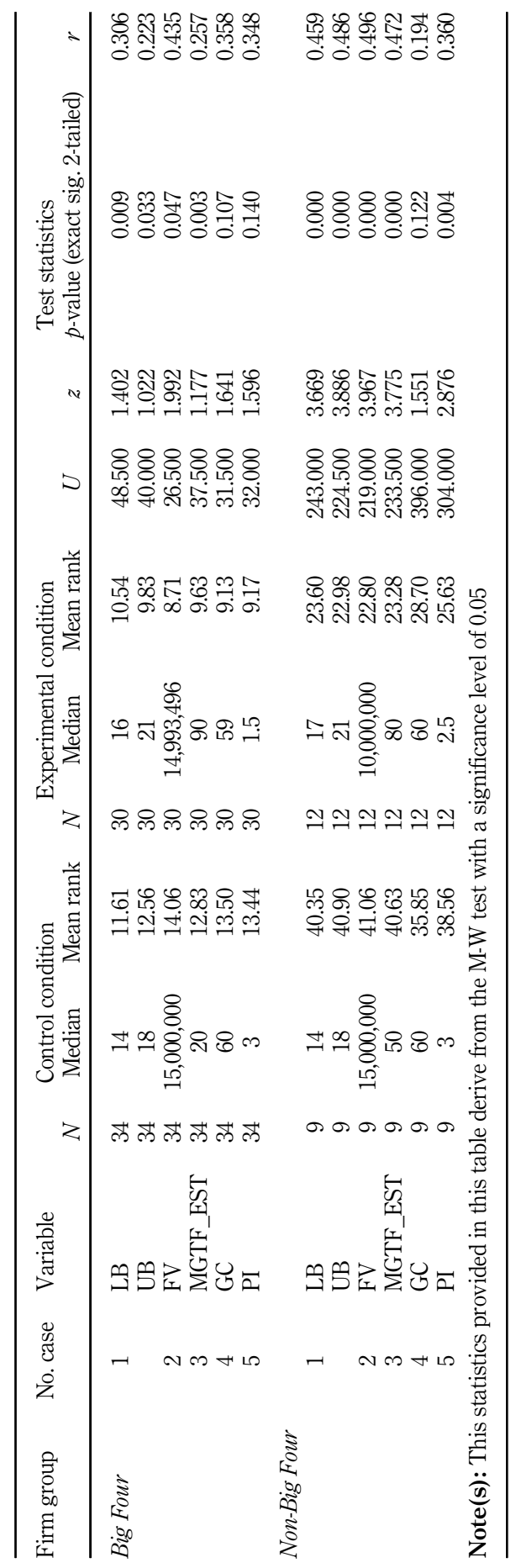

Table 6. Test of hypothesis 2 over all experimental cases 
medium effect size. For the non-Big Four group, the variable FV has a $p$-value of $p=0.000$ and an effect size of $r=0.472$, which can be interpreted as almost strong. Therefore, the hypothesis 2 about the differences between Big Four and non-Big Four audit firms is supported.

For the hypothesis 3, we created two groups regarding the years of experiences the participants stated in the supplemental questionnaire. Using the unweighted mean value of years of experience, we separated the participating auditors in an experienced group and in a less experienced group. The results of this analysis over all experimental cases are summarized in Table 7. Experienced auditors show only for three of the five case exercise significant results. Less experienced auditors are more susceptible for the anchoring and adjustment heuristic. In addition, the effect sizes for the significant results in the less experienced auditor group are also higher. This supports the conclusion that experienced auditors might tend to be less prone to biases deriving from the anchoring and adjustment heuristic. Hence, there is some proof for the third hypothesis.

The fourth hypothesis presumed that there are differences in Swiss audit judgments with regard to anchoring and adjustment heuristic with respect to the auditors' knowledge of behavioral audit since auditors with knowledge about behaviorism and anchor heuristic might tend to be less prone to biases. To examine this hypothesis, we separated the participants on the basis of their knowledge about behaviorism and anchor heuristic, which was asked in the post-experimental questionnaire, and compared the differences between the control and experimental groups of auditors with knowledge of behavioral audit to the differences between the control and experimental groups of auditors with no knowledge of behavioral audit. The results are presented in Table 8 and indicate support for this hypothesis. For the auditors, without any knowledge about anchor heuristic, all five experimental cases are statistically significant. For auditors with appropriate knowledge, only two of five experimental cases verify significant differences between the control and experimental groups.

\subsection{Statistics on the post-experimental questionnaire}

After the exercises, the participants were asked questions in order to understand what influences the judgment of Swiss auditors. Thereby, the participants had to answer several "yes or no" questions about different influential triggers. For questions that were denied, participants were redirected to the next question, whereas those who answered "yes" had to provide further information. The descriptive statistics of the post-experimental questions are provided in Table 9, and the entire post-experimental questionnaire is supplied in the Appendix.

As per INFL_Y/N, only $40 \%$ of Swiss auditors have encountered situations where information provided by the client may have hindered them from judging objectively (e.g. being influenced by sophisticated documents or by information gathered during small talking with the client). However, INFL (mean $=1.97, \mathrm{SD}=0.58$ ) demonstrates that such situations rarely occur (i.e. not more than 5 times a year). Remarkably, more auditors in Switzerland encountered situations where they were unsure how to complete a task in audit $(74.1 \%)$. Out of those, approximately $90 \%$ helped themselves by making use of working papers from prior periods or from similar engagements. Furthermore, the same auditors reckon that the use of other working papers influenced their judgments moderately as stated by $I N F L \_W P($ mean $=5.25, \mathrm{SD}=1.80)$ using a 10 -point scale, ranging from $1=$ no influence and $10=$ high influence. Interestingly, the same share of auditors as for UNCT_Y/N encountered situations where time or budget constraints impeded appropriate assessment of the client's information. Moreover, those 63 audit professionals indicated that such time or budget constraints occur a few times per year (mean $=2.56, \mathrm{SD}=1.06$ ), using a 5 -point rating scale, ranging from $1=$ one time and $5=$ very often [2]. Nevertheless, auditors believe that 


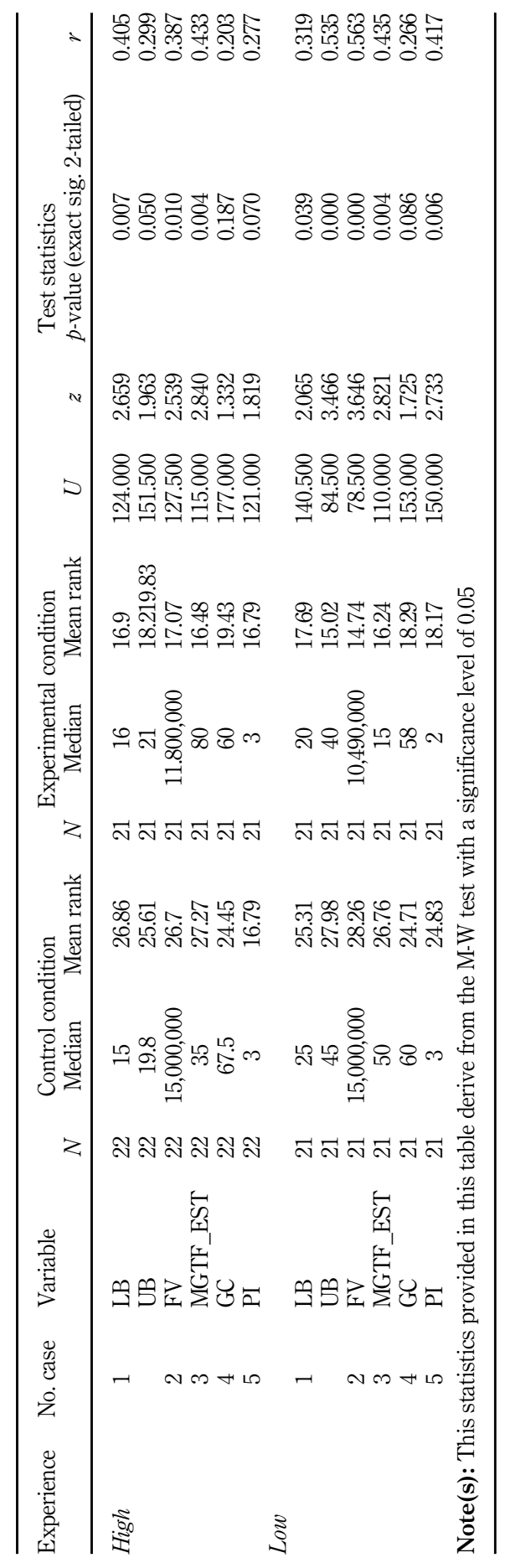

Table 7. Test of hypothesis 3 over all experimental cases 


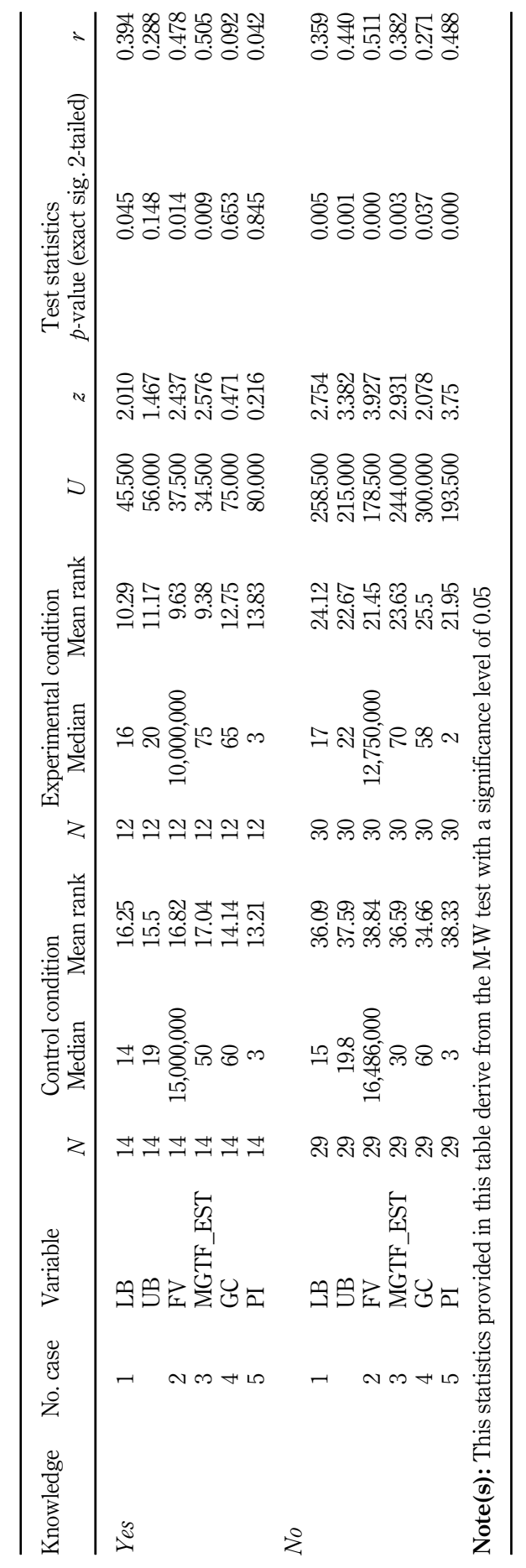

Table 8 .
Test of hypothesis 4 over all experimental cases

$<$ 


\begin{tabular}{|c|c|c|c|c|c|c|c|}
\hline Variable & & $N$ & $\%$ & Mean & $\mathrm{SD}$ & Definition & \\
\hline \multirow[t]{3}{*}{ INFL_Y/N } & & & & & & Participants were asked whether they have ever been & \\
\hline & Yes & 34 & 40.0 & & & influenced by information received from the client that & \\
\hline & No & 51 & 60.0 & & & hindered them from judging objectively (yes or no) & \\
\hline INFL & & 34 & $\mathrm{n} / \mathrm{a}$ & 1.97 & 0.58 & $\begin{array}{l}\text { Participants' perception of being influenced by clients' } \\
\text { information using a } 5 \text {-point scale anchored on } 1=\text { one } \\
\text { time to } 5=\text { very often }\end{array}$ & \\
\hline \multirow[t]{3}{*}{ UNCT_Y/N } & & & & & & Participants were asked whether they have ever felt & \\
\hline & Yes & 63 & 74.1 & & & unsure about how to solve a task in audit (yes or no) & \\
\hline & No & 22 & 25.9 & & & & \\
\hline \multirow[t]{2}{*}{ WPPY_Y/N } & & & & & & Participants were asked whether they have ever made use & \\
\hline & $\begin{array}{l}\text { Yes } \\
\text { No }\end{array}$ & $\begin{array}{r}59 \\
4\end{array}$ & $\begin{array}{r}93.7 \\
3.3\end{array}$ & & & $\begin{array}{l}\text { of prior year audit work or files of similar clients in order } \\
\text { to understand their task (ves or no) }\end{array}$ & \\
\hline INFL_WP & & 59 & $\mathrm{n} / \mathrm{a}$ & 5.25 & 1.80 & $\begin{array}{l}\text { Participants' perception of being influenced by prior year } \\
\text { audit work or less of similar clients per period using a } \\
10 \text {-point scale anchored on } 1=\text { no influence to } 10=\text { highly } \\
\text { influences }\end{array}$ & \\
\hline \multirow[t]{2}{*}{ TBCS_Y/N } & & & & & & Participants were asked whether they have ever & \\
\hline & Yes & $\begin{array}{l}63 \\
22\end{array}$ & 25.1 & & & encountered time or budget constraints at work impeding & \\
\hline TBCS & & 63 & $\mathrm{n} / \mathrm{a}$ & 2.56 & 1.06 & $\begin{array}{l}\text { Participants' perception of being influenced by budget or } \\
\text { time constrains per period using a } 5 \text {-point scale anchored } \\
\text { on } 1=\text { one time to } 5=\text { very often }\end{array}$ & \\
\hline INFL_TBCS & & 63 & $\mathrm{n} / \mathrm{a}$ & 3.16 & 1.3 & $\begin{array}{l}\text { Participants' perception of coming to a different } \\
\text { conclusion under time and budget constraints using a } \\
\text { 10-point scale anchored on } 1=\text { no difference to } \\
10=\text { totally different }\end{array}$ & \\
\hline \multirow[t]{3}{*}{ KNBA_Y/N } & & & & & & $\begin{array}{l}10=\text { totally different } \\
\text { Participants were asked whether they know about }\end{array}$ & $\begin{array}{r}\text { Table } 9 . \\
\text { Descriptive statistics }\end{array}$ \\
\hline & Yes & 26 & & & & behavioral audit (yes or no). If yes, they were furthermore & on post experimental \\
\hline & No & 59 & & & & asked from where they had heard about behavioral audit & \\
\hline
\end{tabular}

time and budget constraints have a low impact on their decision-making as stated by INFL_TBCS $($ mean $=3.16, \mathrm{SD}=1.30$ ) using a 10 -point scale, ranging from $1=$ no difference to $10=$ totally different conclusion.

Moreover, the participants were asked about their knowledge of behavioral audit. Only $30 \%$ of all participants have knowledge about behaviorism and behavioral audit. This prevailing lack of know-how may indicate how distorted the understanding of decisionmaking in auditing in Switzerland is. Most of the participants with knowledge about behaviorism were sensitized on the job (54\%) or during their former education $(46 \%)$ rather than at their CPA institution (15\%).

Overall, the results suggest that the highest influence in Swiss audit judgments derives from internally tested sources such as prior year working papers or similar engagements. External sources such as client's information or time and budget constraints are believed to have a remarkable lower impact on audit judgments in Switzerland. Furthermore, less than a third of the participants were aware that they employed heuristics when solving the experimental cases.

\section{Discussion and conclusion}

In this study, we examined the anchoring and adjustment effects on Swiss audit judgments. In particular, the results of this study offer practical and theoretical contributions by examining if the anchor heuristic biases the Swiss auditors' judgment and if audit firm size, work experience and knowledge of behavioral audit impact this bias. 
Based on the results of the experiment, this study finds evidence on the existence of the anchoring and adjustment heuristic in Swiss audit judgment as all five experimental cases yield statistically significant differences in the participant's median estimates. In addition, the extent of this finding is insofar remarkable as the effect sizes indicate solid medium effects over all variables observed. Therefore, we conclude that auditors in Switzerland employ the anchoring and adjustment heuristic to an extent that could lead to biased judgments. Consistent with our expectations, the audit firm size has an influence on the audit judgment with regard to the anchoring and adjustment heuristic. Auditors from Big Four firms are less biased in audit decisions by the impact of an anchor heuristic.

Furthermore, a relationship is found between the years of experience in auditing and the bias driven by the anchor. Less experienced auditors are more susceptible for the anchoring and adjustment heuristic than their experienced colleges. Beyond that, we identified anchoring and adjustment effects depending on the experience in auditing. Another interesting finding is that approximately $70 \%$ of the participants believe that the use of working papers from prior periods or similar clients has a moderate influential impact on their judgment. Furthermore, only about $30 \%$ of the participants indicated to having knowledge about behaviorism. Accordingly, this study discloses a remarkable gap of knowledge in Swiss auditors with regard to behavioral disciplines.

Finally, the results reveal that knowledge about behaviorism and anchor heuristic can prevent heuristics and biases in audit judgment, which has not been investigated in former studies regarding behaviorism in auditing. It is therefore advisable to increase the awareness and understanding of behaviorism in the Swiss audit environment. Ideally, professional judgment is the connecting factor for such an endeavor, since it has been shown to be the source of judgmental biases in auditing.

In summary, the prevailing debasing measure is to increase the awareness of the employment of heuristics in Swiss audit judgments. The main objective, therefore, is that auditors must know about behaviorism before implementing other measures. One broad approach for lessening the impact of cognitive biases on human judgments is the application of a critical-thinking strategy and professional skepticism. Critical thinking involves a conscious and iterative process of reflecting, evaluating and challenging one's own decision and decision-making process with the intent of improving each. If properly applied, this strategy can help decision-makers identify cognitive biases influencing their decisions and then choose the specific measures that should be useful in controlling or eliminating them (see also Knapp and Knapp, 2012). Cognitive biases can impair the decision-making process of any auditor. Being aware of the many different biases that typically affect auditors' decisionmaking is the first step in overcoming them. Professional skepticism can help auditors to guard against cognitive biases during audit engagements.

With respect to auditing theory and practice, our results suggest auditors should be aware of succumbing to anchoring and adjustment heuristics when processing information; thus, auditors should be especially vigilant when initial information is not proven or verifiable. This should be of particular concern to audit firms, as this is likely to correlate with risks to the audit firm (e.g. litigation risk, reputation risk). Further, the present findings have implications for both research and audit education. First, the present study contributes to the professional skepticism literature by responding to a call for more research on enhancing professional skepticism (e.g. Hurtt et al., 2013; Nelson, 2009). Second, the results of the present study may provide insights to educators who attempt to improve course curricula to meet multiple goals of accounting programs. Professional skepticism is an important professional responsibility that educators should highlight in accounting education (Luan, 2013). Our findings suggest the effectiveness of training and education in cognitive bias and its attenuation in promoting professional skepticism. 
As with all experimental research, this study has a number of potential limitations that should be considered when evaluating the results. First, the experimental tasks were relatively simple abstractions from the more complex analytical review situations faced by practicing auditors. Traditionally, auditors who perform analytical procedures have extensive knowledge of and experience with the client, thereby having a broader base from which to create an analytical expectation. However, we hoped that auditors would view these scenarios as abstractions of situations that they typically encounter and respond as they would in practice. Second, despite the fact that we draw a random sample and perform a non-response test, we cannot ensure any representativeness of the results. Third, our sample size is rather small which may limit the power of our analysis and the generalizability of our findings. Fourth, even though we find differences between the effect of anchoring and adjustment heuristic for different auditor groups (Big Four vs non-Big Four, experienced vs less experienced, and with knowledge vs without knowledge about behavioral audit), we cannot state if the underlying audit topic or the used anchor and bias heuristic is responsible for the statistical differences, that is, if auditors are less prone to bias and heuristics in judgment and decision-making in specific audit areas or if the observed bias is responsible for the variation. Therefore, future research could investigate, on the one hand, the influence of different heuristics on auditors' judgment and, on the other hand, the impact on different audit topics.

\section{Notes}

1. The Mann-Whitney $U$ test is sensitive to differences in medians between two groups.

2. Where $2=$ rarely and $3=$ sometimes (i.e. $2-5$ times and $6-15$ times of occurrence per year, respectively).

\section{References}

Abdolmohammadi, M. and Wright, A. (1987), "An examination of the effects of experience and task complexity on audit judgments", The Accounting Review, Vol. 62 No. 1, pp. 1-13.

American Institute of Certified Public Accountants (AICPA) (2007), Consideration of Fraud in a Financial Statement Audit' AU Section 316, AICPA, New York.

Amir, E., Kallunki, J.P. and Nilsson, H. (2014), "The association between individual audit partners' risk preferences and the composition of their client portfolios", Review of Accounting Studies, Vol. 19 No. 1, pp. 103-133.

Arens, A.A., Elder, R.J. and Beasly, M.S. (2012), Auditing and Assurance Services, 14th ed., Prentice Hall, New Jersey.

Ashton, R.H. (1984), "Integrating research and teaching in auditing: fifteen cases on judgment and decision-making", The Accounting Review, Vol. 59 No. 1, pp. 78-97.

Ashton, R.H. (1990), "Pressure and performance in accounting decision settings: paradoxical effect of incentives, feedback, and justification", Journal of Accounting Research, Vol. 28, pp. 148-180.

Bedard, J.C., Deis, D.R., Curtis, M.B. and Jenkins, J.G. (2008), "Risk monitoring and control in audit firms: a research synthesis", Auditing: A Journal of Practice and Theory, Vol. 27 No. 1, pp. 187-218.

Bedard, J.C. and Wright, A.M. (1994), "The functionality of decision heuristics: reliance on prior audit adjustments in evidential planning", Behavioral Research in Accounting, Vol. 6 No. Supplement, pp. 62-89.

Bhattacharjee, S., Moreno, K.K. and Riley, T. (2012), "Interplay of interpersonal affect and source reliability on auditors' inventory judgments”, Contemporary Accounting Research, Vol. 29 No. 4, pp. 1087-1108. 
Biggs, S.F. and Wild, J.J. (1985), "An investigation of auditor judgment in analytical review", The Accounting Review, Vol. 60 No. 4, pp. 607-633.

Blokdijk, H., Drieenhuizen, F., Simunic, D.A. and Stein, M. (2006), "An analysis of cross-sectional differences in big and non-big public accounting firms' audit programs", Auditing: A Journal of Practice and Theory, Vol. 25 No. 1, pp. 27-48.

Bonner, S.E. (1999), "Judgment and decision-making research in accounting", Accounting Horizons, Vol. 13 No. 4, pp. 385-398.

Bucaro, A.C. (2019), "Enhancing auditors' critical thinking in audit of complex estimates", Accounting, Organizations and Society, Vol. 73, pp. 35-49.

Butler, S.A. (1986), "Anchoring in the judgmental evaluation of audit samples", The Accounting Review, Vol. 61 No. 1, pp. 101-111.

Chapman, G.B. and Johnson, E.J. (1999), "Anchoring, confirmatory search, and the construction of values”, Organizational Behavior and Human Decision Processes, Vol. 79 No. 2, pp. 115-153.

Che, L., Hope, O.K. and Langli, J.C. (2017), "Does the big-4 effect exist in the private-client segment? Evidence from audit-partner - auditee pair switches", available at: https://ssrn.com/ abstract $=2828224$.

Chen, T. and Wang, H. (2018), "Auditors with or without styles? Evidence from unexpected auditor turnovers", Working paper, Hong Kong University of Science and Technology.

Cheng, P.Y.K. (2011), "Improving audit judgment and decision-making with dual systems cognitive model", Journal of Modern Accounting and Auditing, Vol. 7 No. 10, pp. 1060-1069.

Choi, J.H., Kim, C., Kim, J.B. and Zang, Y. (2010), “Audit office size, audit quality, and audit pricing”, Auditing: A Journal of Practice and Theory, Vol. 29 No. 1, pp. 73-97.

Choo, F. and Tan, K. (2000), "Instruction, skepticism, and accounting students' ability to detect frauds in auditing", Journal of Business Education, Vol. 1, pp. 72-87.

Cohen, J.R., Dalton, D.W. and Harp, N.L. (2017), "Neutral and presumptive doubt perspectives of professional skepticism and auditor job outcomes", Accounting, Organizations and Society, Vol. 62, pp. 1-20.

DeFond, M., Erkens, D.H. and Zhang, J. (2016), "Do client characteristics really drive the big N audit quality effect? New evidence from propensity score matching", Management Science, Vol. 63 No. 11, pp. 3628-3649.

Dowling, C. and Leech, S.A. (2014), "A big 4 firm's use of information technology to control the audit process: how an audit support system is changing auditor behavior", Contemporary Accounting Research, Vol. 31 No. 1, pp. 230-252.

Epley, N. and Gilovich, T. (2001), "Putting adjustment back in the anchoring and adjustment heuristic: differential processing of self-generated and experimenter-provided anchors", Psychological Science, Vol. 12 No. 5, pp. 391-396.

Epley, N. and Gilovich, T. (2006), "The anchoring-and-adjustment heuristic: why the adjustments are insufficient", Psychological Science, Vol. 17 No. 4, pp. 311-318.

Eshleman, J.D. and Guo, P. (2014), "Do big 4 auditors provide higher audit quality after controlling for the endogenous choice of auditor?", Auditing: A Journal of Practice and Theory, Vol. 33 No. 4, pp. 197-219.

Farag, M.S. and Elias, R.Z. (2016), "The relationship between accounting students' personality, professional skepticism and anticipatory socialization”, Accounting Education, Vol. 25 No. 2, pp. 124-138.

Gao, P. and Zhang, G. (2019), "Auditing standards, professional judgement, and audit quality", The Accounting Review, Vol. 94 No. 6, pp. 201-225.

Gilovich, T. and Griffin, D. (2013), "Introduction - heuristics and biases: then and now", in Gilovich, T., Griffin, D. and Kahneman, D. (Eds), Heuristics and Biases, Cambridge University Press, New York, pp. 1-18. 
Glover, S.M. (1997), "The influence of time pressure and accountability on auditors' processing of nondiagnostic information”, Journal of Accounting Research, Vol. 35 No. 2, pp. 213-226.

Gul, F.A., Wu, D. and Zhifeng, Y. (2013), "Do individual auditors affect audit quality? Evidence from archival data", The Accounting Review, Vol. 88 No. 6, pp. 1993-2023.

Hackenbrack, K. (1992), "Implications of seemingly irrelevant evidence in audit judgment", Journal of Accounting Research, Vol. 30 No. 1, pp. 126-136.

Harding, N. and Trotman, K.T. (2017), "The effect of partner communications of fraud likelihood and skeptical orientation on auditors' professional skepticism", Auditing: A Journal of Practice and Theory, Vol. 36 No. 2, pp. 111-131.

Hayes, T. (2016), "Strategies for teaching professional skepticism in the classroom: evidence from senior-level auditing students", International Journal of Business, Accounting, and Finance, Vol. 10 No. 2, pp. 110-121.

He, X., Pittman, J., Rui, O.M. and Wu, D. (2017), "Do social ties between external auditors and audit committee members affect audit quality?", The Accounting Review, Vol. 92 No. 5, pp. 61-87.

He, X., Kothari, S.P., Xiao, T. and Zuo, L. (2018), "Long-term impact of economic conditions on auditors' judgment”, The Accounting Review, Vol. 93 No. 6, pp. 203-229.

Hoffman, V.B. and Patton, J.M. (1997), "Accountability, the dilution effect, and conservatism in auditors' fraud judgments", Journal of Accounting Research, Vol. 35 No. 2, pp. 227-237.

Hurtt, R.K. (2010), "Development of a scale to measure professional skepticism", Auditing: A Journal of Practice and Theory, Vol. 29 No. 1, pp. 149-171.

Hurtt, R.K., Brown-Liburd, H., Earley, C.E. and Krishnamoorthy, G. (2013), "Research on auditor professional skepticism: literature synthesis and opportunities for future research", Auditing: A Journal of Practice and Theory, Vol. 32 No. 1, pp. 45-97.

International Auditing and Assurance Standards Board (IAASB) (2012), Professional Skepticism in an Audit of Financial Statements, IAASB Staff Questions and Answers, IFAC, New York.

International Federation of Accountants (IFAC) (2012), Handbook of International Quality Control, Auditing, Review, Other Assurance, and Related Services Pronouncements, IFAC, New York.

Jenkins, J.G., Deis, D.R., Bedard, J.C. and Curtis, M.B. (2008), “Accounting firm culture and governance: a research synthesis", Behavioral Research in Accounting, Vol. 20 No. 1, pp. 45-74.

Johnson, V.E., Khurana, I.K. and Reynolds, J.K. (2002), "Audit-firm tenure and the quality of financial reports", Contemporary Accounting Research, Vol. 19 No. 4, pp. 637-660.

Joyce, E.J. and Biddle, G.C. (1981), “Anchoring and adjustment in probabilistic inference in auditing”, Journal of Accounting Research, Vol. 19 No. 1, pp. 120-145.

Kadous, K. (2000), "The effects of audit quality and consequence severity on juror evaluations of auditor responsibility for plaintiff losses", The Accounting Review, Vol. 75 No. 3, pp. 327-341.

Kadous, K. and Zhou, Y. (2019), "How does intrinsic motivation improve auditor judgment in complex audit tasks?”, Contemporary Accounting Research, Vol. 36 No. 1, pp. 108-131.

Kahneman, D. and Tversky, A. (1973), "On the psychology of prediction”, Psychological Review, Vol. 80 No. 4, pp. 237-251.

Kartscher, P., Rossi, B. and Suter, D. (2013), Wirtschaftsprüfung - interne und externe Revision [Audit and Assurance - Internal and External Auditing], Schulthess, Zürich.

Kennedy, J. (1995), "Debiasing the curse of knowledge in audit judgment", The Accounting Review, Vol. 70 No. 2, pp. 249-273.

Kinney, W.R. and Uecker, W.C. (1982), "Mitigating the consequences of anchoring in auditor judgments", The Accounting Review, Vol. 57 No. 1, pp. 55-69.

Knapp, M.C. and Knapp, C.A. (2012), "Cognitive biases in audit engagements: errors in judgment and strategies for prevention”, The CPA Journal, June, Vol. 82 No. 6, pp. 40-45. 
Knechel, W.R., Salterio, S.E. and Kochetova-Kozloski, N. (2010), "The effect of benchmarked performance measures and strategic analysis on auditors' risk assessments and mental models", Accounting, Organizations and Society, Vol. 35, pp. 316-333.

Knechel, W.R., Sofla, A.S. and Svanström, T. (2018), "The effect of professional skepticism on auditor compensation and auditor opinions", Working paper, Umeå School of Business and Economics, University of Florida, KU Leuven.

Kowalczyk, T.K. and Wolfe, C.J. (1998), "Anchoring effects associated with recommendations from expert decision aids: an experimental analysis", Behavioral Research in Accounting, Vol. 10 No. Supplement, pp. 147-169.

Lambert, T.A. and Peytcheva, M. (2020), "When is the averaging effect present in auditor judgment?", Contemporary Accounting Research, Vol. 37 No. 1, pp. 277-296.

Lenz, H. and James, M. (2007), "International audit firms as strategic networks: the evolution of global professional service firms", in Cliquet, G., Hendrikse, G.W.J., Tuunanen, M. and Windsperger, J. (Eds), Economics and Management of Networks: Franchising, Strategic Alliances, Cooperatives, Physica-Verla, New York, pp. 367-392.

Libby, R. (1981), Accounting and Human Information Processing: Theory and Applications, Prentice Hall, NJ.

Low, K.Y. (2004), "The effect of industry specialization on audit risk assessments and audit-planning decisions", The Accounting Review, Vol. 79 No. 1, pp. 201-219.

Luan, F. (2013), "On accounting education ideas”, Accounting Research, Vol. 4, pp. 22-27.

Mactravish, C., Mccracken, S. and Schmidt, R.N. (2018), "External auditors' judgment and decision making: an audit process task analysis", Accounting Perspectives, Vol. 17 No. 3, pp. 387-426.

Mala, R. and Chand, P. (2015), "Judgment and decision-making research in auditing and accounting: future research implications of person, task, and environment perspective", Accounting Perspectives, Vol. 14 No. 1, pp. 1-50.

McDaniel, L.S. (1990), "The effects of time pressure and audit program structure on audit performance", Journal of Accounting Research, Vol. 28 No. 2, pp. 267-285.

McMillan, J.J. and White, R.A. (1993), "Auditors' belief revisions and evidence search: the effect of hypothesis frame, confirmation and professional skepticism", The Accounting Review, Vol. 68 No. 3, pp. 443-465.

Nelson, M.W. (2009), "A model and literature review of professional skepticism in auditing”, Auditing: A Journal of Practice and Theory, Vol. 28 No. 2, pp. 1-34.

Nisbett, R.E., Zukier, H. and Lemley, R.E. (1981), "The dilution effect: nondiagnostic information weakens the implications of diagnostic information”, Cognitive Psychology, Vol. 13 No. 2, pp. 248-277.

Nugraha, A.S. and Suryandari, D. (2018), "The effect of experience to the accuracy of giving opinion with audit expertise, professional skepticism, audit judgment as mediators", Accounting Analysis Journal, Vol. 7 No. 1, pp. 61-69.

Olsen, C. and Gold, A. (2018), "Future research directions at the intersection between cognitive neuroscience research and auditors' professional skepticism", Journal of Accounting Literature, Vol. 41, pp. 127-141.

Owhoso, V.E., Messier, W.F., Jr and Lynch, J.G., Jr (2002), "Error detection by industry-specialized teams during sequential audit review", Journal of Accounting Research, Vol. 40 No. 3, pp. 883-900.

Peecher, M.E., Schwartz, R. and Solomon, I. (2007), "It's all about audit quality: perspectives on strategic systems auditing", Accounting, Organizations and Society, Vol. 32, pp. 463-485.

Pike, B.J., Curtis, M.B. and Chui, L. (2013), "How does an initial expectation bias influence auditors' application and performance of analytical procedures?”, The Accounting Review, Vol. 88 No. 4, pp. 1413-1431. 
Popova, V. (2013), "Exploration of skepticism, client-specific experiences, and audit judgments", Managerial Auditing Journal, Vol. 28 No. 2, pp. 140-160.

Prawitt, D.F. (1998), "Commentary on anchoring effects associated with recommendations from expert decision aids: an experimental analysis", Behavioral Research in Accounting, Vol. 1 No. Supplement, pp. 170-181.

Presutti, A.H. (1995), "Anchor and adjustment heuristic effect on audit judgement", Managerial Auditing Journal, Vol. 10 No. 9, pp. 13-21.

Public Company Accounting Oversight Board (PCAOB) (2008), Proposed Auditing Standards Related to the Auditor's Assessment of and Response to Risk and Conforming Amendments to PCAOB Standards, PCAOB Release No. 2008-006, PCAOB, Stamford.

Quadackers, L., Groot, T. and Wright, A. (2014), “Auditors' professional skepticism: neutrality versus presumptive doubt", Contemporary Accounting Research, Vol. 31 No. 3, pp. 639-657.

Rodgers, W., Mubako, G.N. and Hall, L. (2017), "Knowledge management: the effect of knowing transfer on professional skepticism in audit engagement planning", Computers in Human Behavior, Vol. 70, pp. 564-574.

Rose, J.M. (2007), "Attention to evidence of aggressive financial reporting and intentional misstatement judgments: effects of experience and trust", Behavioral Research in Accounting, Vol. 19 No. 1, pp. 215-229.

Shanteau, J. (1989), "Cognitive heuristics and biases in behavioral auditing: review, comments and observations", Accounting, Organizations and Society, Vol. 14 Nos 1/2, pp. 165-177.

Shaub, M.K. (1996), "Trust and suspicion: the effects of situational and dispositional factors on auditors' trust of clients", Behavioral Research in Accounting, Vol. 8, pp. 154-174.

Shelton, S.W. (1999), "The effect of experience on the use of irrelevant evidence in auditor judgment", The Accounting Review, Vol. 74 No. 2, pp. 217-224.

Simon, H. (1957), Models of Man: Social and Rational, Wiley, New York.

Slovic, P. and Lichtenstein, S. (1971), "Comparison of Bayesian and regression approaches to the study of information processing in judgment", Organizational Behavior and Human Performance, Vol. 19, pp. 649-744.

Smith, J. and Kida, T. (1991), "Heuristics and biases: expertise and task realism in auditing", Psychological Bulletin, Vol. 109 No. 3, pp. 472-489.

Solomon, I., Shields, M.D. and Whittington, O.R. (1999), "What do industry-specialist auditors know?", Journal of Accounting Research, Vol. 37 No. 1, pp. 191-208.

Teoh, S. and Wong, T. (1993), "Perceived auditor quality and the earnings response coefficient", The Accounting Review, Vol. 68 No. 2, pp. 346-366.

Thorngate, W. (1980), "Efficient decision heuristics", Behavioral Science, Vol. 15 No. 3, pp. 219-225.

Treuhand-Kammer (2013), Schweizer Prüfungsstandard (PS) SAS 520 - Analytische Prüfungshandlungen' [Swiss Fiduciary Chamber, Swiss Audit Standard, SAS 520 Analytical Audit Procedures], Treuhand-Kammer, Zürich.

Tversky, A. and Kahneman, D. (1974), "Judgment under uncertainty: heuristics and biases", Science, Vol. 185, pp. 1124-1130.

Wedemeyer, P.D. (2010), "A discussion of auditor judgment as the critical component in audit quality - a practitioner's perspective”, International Journal of Disclosure and Governance, Vol. 7 No. 4, pp. 320-333.

Westermann, K.D., Cohen, J. and Trompeter, G. (2016), "A qualitative examination of the perceived influence of accountability on professional skepticism", available at: http://www.isarhq.org/ 2014_downloads/papers/ISAR2014_Westermann_Cohen_Trompeter.pdf (accessed 24 October 2017). 
Wilson, T.D., Houston, C.E., Etling, K.M. and Brekke, N. (1996), “A new look at anchoring effects: basic anchoring and its antecedents", Journal of Experimental Psychology, Vol. 125 No. 4, pp. 387-402.

Wright, W.F. and Anderson, U. (1989), "Effects of situation familiarity and financial incentives on use of the anchoring and adjustment heuristic for probability assessment", Organizational Behavior and Human Decision Processes, Vol. 44 No. 1, pp. 68-82.

\section{Further reading}

Kahneman, D. (2011), Thinking, Fast and Slow, Penguin, London.

Kahneman, D. and Frederick, S. (2013), "Representativeness revisited: attribute substitution in intuitive judgment”, in Gilovich, T., Griffin, D. and Kahneman, D. (Eds), Heuristics and Biases, Cambridge University Press, New York, pp. 49-81.

Kahneman, D. and Tversky, A. (1984), "Choices, values, and frames”, American Psychologist, Vol. 39 No. 4 , pp. 341-350.

Kinney, W.R. (1979), "The predictive power of limited information in preliminary analytical review: an empirical study", Journal of Accounting Research, Vol. 17, pp. 148-165.

\section{Corresponding author}

Philipp Henrizi can be contacted at: philipp.henrizi@hslu.ch 